\title{
Relating soil erosion and sediment yield to geomorphic features and erosion processes at the catchment scale in the Spanish Pre-Pyrenees
}

\author{
Manuel López-Vicente* · Ana Navas
}

Department of Soil and Water, Experimental Station of Aula Dei - CSIC. Avda. Montañana 1005, 50059 Zaragoza, Spain.

*e-mail: mvicente@eead.csic.es; mlopezvicente@gmail.com

---- Published on Environmental Earth Sciences 61(1), 143-158, DOI 10.1007/s12665-009-0332-x (18 June 2010) ------- Published online 7 November 2009 in Springer Link ----

---- Received 4 February 2009; Accepted 20 October 2009 ----

\begin{abstract}
Erosion and sediment redistribution are important processes in landscape changes in the short and long term. In this study, the RMMF model of soil erosion and the SEDD model of sediment delivery were used to estimate annual soil loss and sediment yield in an ungauged catchment of the Spanish Pre-Pyrenees and results were interpreted in the context of the geomorphic features. The Estaña Catchment is divided into 15 endorheic sub-catchments and there are 17 dolines. Gullies and slopes were the main erosive geomorphic elements, whereas the colluvial, alluvial, valley floor, and doline deposits were depositional elements. Spatially distributed maps of gross soil erosion, sediment delivery ratio $(S D R)$, and sediment yield $(S Y)$ were generated in a GIS. Severe erosion rates (> $100 \mathrm{Mg} \mathrm{ha}^{-1} \mathrm{yr}^{-1}$ ) were found in gullies, whereas mean and maximum erosion rates were very high on slopes developed on Keüper Facies and high in soils on Muschelkalk Facies. Where crops are grown, the depositional-type geoforms were predicted by the models to have an erosive dynamic. Those results were consistent with the rates of erosion quantified by ${ }^{137} \mathrm{Cs}$ which reflects the significant role of human activities in triggering soil erosion. Catchment area was positively correlated with erosion rate, but negatively correlated with $S D R$ and $S Y$. The latter were negatively correlated with the proportion of the surface catchment covered with forests and scrublands. The topography of the area influenced the high $S D R$ and $S Y$ in the dolines and valley floors near the sinks. Intra-basin stored sediment was $59.2 \%$ of the total annual eroded soil in the catchment. The combination of the RMMF and SEDD models was an appropriate means
\end{abstract}


of assessing the effects of land uses on soil erosion and obtaining a better understanding of the processes that underlie the geomorphic changes occurring in mountainous environments of the Mediterranean region.

Keywords RMMF model · SEDD model · Soil erosion · Sediment delivery and yield · Geomorphology

\section{Introduction}

Field observations have confirmed that models have predicted correctly that erosion and the associated sediment deposition mainly are influenced by geomorphology and land uses (Pelacani et al. 2008), and a few daily erosive events. These observations are essential for the reconstruction of the geomorphic history of a landscape, especially in Mediterranean regions (González-Hidalgo et al. 2007). Often, studies of the relationships between changes in erosion, deposition, and landscape are assessed at long- $\left(>10^{3} \mathrm{yr}\right)$ or medium-term $\left(10^{2}-10^{3} \mathrm{yr}\right)$ scales (Hunt et al. 2007; Xu et al. 2007). Reconstruction of the landscape from the past to the present can be done by integrating information on topography, geomorphology, soil, and vegetation conditions (Hunt and Wu 2004). Estimates of total soil erosion and sediment export rates are of value in describing the current erosive dynamics at the catchment scale and, in the context of geomorphic features, help to identify temporal changes in these dynamics.

From various sources, sediments are distributed throughout the basin and the sediment delivery ratio at watershed scale $\left(S D R_{W}\right)$ is the fraction of gross eroded soil ( $E$, $\mathrm{Mg} \mathrm{ha}^{-1} \mathrm{yr}^{-}$ ${ }^{1}$ ) that is delivered to the outlet of the area drained (Ferro and Minacapilli 1995). Thus, the $S D R_{W}$ reflects the integrated capacity of a catchment for storing and transporting the eroded soil; however, in the long-term $(>\sim 1000 \mathrm{yr})$, all of the eroded sediments are likely to be exported from the basin.

Recent studies of the sediment delivery process suggest that the relationship between area-specific sediment yield ( $\left.S S Y, \mathrm{Mg} \mathrm{ha}^{-1} \mathrm{yr}^{-1}\right)$ and basin area $\left(A_{W}\right.$, ha) is complex and non-linear, and slope gradients, land-cover conditions, and human impact determine whether hillslope erosion or channel erosion predominates and controls the relationship between $S S Y$ and $A_{W}$ (de Vente et al. 2007).

Most of the soil erosion models account for processes associated with splash, sheet, rill, and ephemeral gully erosion, only, while few studies consider gully and channel erosion, mass movements, sediment delivery, and deposition processes. The coupling of 
soil erosion and transport models improves the goodness-of-fit of predictions of spatially distributed soil loss and redistribution (de Vente et al. 2008), especially in active geomorphic features such as gullies (Hessel and Jetten 2007), and allows detailed geomorphological reconstructions (de Moor and Verstraeten 2008).

In the last decade, predictive models of soil erosion and sediment yield have been modified to accommodate catchment and basin spatial scales and GIS techniques; e.g. the semi-physically based Revised Morgan, Morgan and Finney model (RMMF; Morgan 2001) of soil loss and the Sediment Delivery Distributed model (SEDD; Ferro and Porto 2000; Ferro and Minacapilli 1995). Other models, such as the LISEM model (De Roo et al. 1996), which operates at the event scale, and the WaTEM/SEDEM model (Van Rompaey et al. 2001), which operates at the mean annual scale, integrate the soil erosion, transport, yield, and deposition processes. Few studies, however, have focused on the short-term fit between spatially distributed maps of soil loss and sediment delivery and the geomorphic elements and processes of the redistribution of soil particles (O'Farrell et al. 2007). The potential of using models of soil erosion and sediment delivery to describe the geomorphic processes at the catchment scale has emerged as an area of scientific interest.

The RMMF model has a moderate number of inputs and has been used to estimate soil erosion and deposition under several land-use and climate scenarios (Scholz et al. 2008; Vigiak et al. 2005; Svorin 2003). Moreover, the RMMF model provides a stronger physical basis than do other empirical models such as the RUSLE model, although it retains the advantages of an empirical approach with its ease of use and availability of data (Morgan 2001). The SEDD model predicts sediment delivery and yield at the basin scale based on previous maps of soil erosion and is easy to run within a GIS. Often, the SEDD model and the empirical RUSLE model (Renard et al. 1997) of soil erosion have been combined (Di Stefano and Ferro 2007). In the last decade, the use of the SEDD model to predict sediment export under various climatic and topographic conditions and land-use scenarios has increased (e.g., Di Piazza et al. 2007; Yang et al. 2007), and it is of interest to estimate sediment delivery and yield in areas that have complex topographies.

This work aims to predict annual soil loss, sediment delivery, and sediment yield with the RMMF and SEDD models in a Mediterranean catchment that had a large variety of land uses. In addition, we compared the generated maps of soil erosion and sediment yield to the map of the main erosive and depositional geoforms. The spatially distributed analysis of these maps permitted characterization of the intensity of the erosive dynamic in the study area with special attention to the effect of anthropogenic impacts. To that end, 
we studied an ungauged, complex karstic catchment, the Estaña Catchment, in the Central Pre-Pyrenees (NE Spain), which is divided into 15 endorheic sub-catchments. The coupling of the RMMF and SEDD models, the use of a detailed database, and high spatial resolution within a GIS framework allowed us to map the spatially distributed rates of annual gross soil erosion and sediment yield. The overarching objective of this study is to better understand the most important erosion processes and factors controlling sediment export at the endorheic catchment scale under current land use and climate scenarios. The identification of source areas and predictions of soil erosion and delivery processes in the short-term help in identifying changes in the erosive dynamic within the catchment.

\section{Materials and methods}

Study area

The Estaña Catchment (246 ha), in the External Ranges of the Central Spanish PrePyrenees, is at an elevation of 676-896 $\mathrm{m}$ a.s.l. and has an average slope steepness of $19 \%$ (Fig. 1a). The catchment includes three freshwater lakes (total area $=17$ ha) that have been under regional protection since 1997 and are included in the European NATURA 2000 Network as a Site of Community Importance (SCI). In addition, there are 15 subcatchments, which range in size from 0.1 to 120 ha, and streams are ephemeral. The study area consists of Mesozoic and Neogene materials that include gypsiferous marls, dolomites, limestones, ophites, and sparse saline deposits. The Mesozoic materials are outcrops of Keüper and Muschelkalk Facies. Karstic and hydrologic processes have shaped the genesis and evolution of the Estaña Catchment as a part of the paleopolje of Saganta since the upper boundary of the Miocene Period (Sancho Marcén 1988). The area has 17 dolines, 12 systems of gullies, an ephemeral stream, and diverse deposits (Fig. 1b) (López-Vicente et al. 2009). The colluvial, alluvial, doline, and valley floor deposits are associated with depositional processes that occurred during the Quaternary inter-glacial periods (Sancho Marcén 1988). In the middle-north of the Estaña Catchment, the colluvial deposit is being eroded by a system of gullies, which suggests a change in the intensity and spatial distribution of the erosion and deposition processes toward a more erosive context in relation to the inter-glacial periods. Karstic processes of overland flow infiltration only occur at the bottom of the sub-catchments where boulder grounds occur. Overland flow does not disappear along the hillslopes and karstic processes do not affect runoff generation or soil erosion. 
In the last few centuries, humans have greatly modified the Estaña Catchment and, in 2008, there were 17 different land uses (Fig. 1a). The map of land uses was created using GIS, a coloured orthophoto of the study area, and field identification of the types of cover. Natural and anthropogenic areas were heterogeneously distributed with frequent changes in land use from the divides to slope-bottoms and a wide range of patch sizes. Winter barley was the main land use (29\% of the area). The remainder was dense (18\%) and open (18\%) Mediterranean forests, and dense (10\%) and sparse (5\%) scrublands. Other land uses comprised $<5 \%$ and occurred throughout the study area.

In northern Spain, the climate is continental Mediterranean, there are humid periods in spring (April and May) and autumn (September and October), and summers are dry with frequent, high-intensity rainfall events (López-Vicente et al. 2008a). In the period 19932006, average annual precipitation was $595 \mathrm{~mm}$ in the Estaña Catchment and their average minimum and maximum temperatures were $6.0{ }^{\circ} \mathrm{C}$ and $18.8^{\circ} \mathrm{C}$, respectively (Fig. 1a) (López-Vicente 2008).

\section{The RMMF model of soil erosion applied in a GIS}

The semi-physically based RMMF (Revised Morgan, Morgan and Finney) model (Morgan 2001) calculates the annual rate of soil erosion per grid cell ( $\left.E_{i}, \mathrm{Mg} \mathrm{ha}^{-1} \mathrm{yr}^{-1}\right)$ as the minimum total soil detachment and sediment transport capacity in the grid cell (see Equation 1). Total soil detachment is calculated as the sum of soil detachment by splash erosion $\left(F, \mathrm{Mg} \mathrm{ha}^{-1} \mathrm{yr}^{-1}\right)$ and erosion due to runoff $\left(H, \mathrm{Mg} \mathrm{ha}^{-1} \mathrm{yr}^{-1}\right)$.

$$
E_{i}=\min \{(F+H), T C\}
$$

Soil detachment by splash

In the RMMF, effective rainfall $(E R, \mathrm{~mm})$ is the volume of the total annual rainfall $(R$, $\mathrm{mm}$ ) that is not intercepted $(A, \%)$ by canopy cover and reaches the soil as direct throughfall $(D T, \mathrm{~mm})$ or leaf drainage $(L D, \mathrm{~mm})$.

$$
\begin{aligned}
& E R=R A \\
& L D=E R C C \\
& D T=E R-L D
\end{aligned}
$$

where $C C$ (\%) is the proportion of the soil covered by canopy. Equations (3) and (4) explain how the RMMF model splits the volume of effective rainfall into the direct throughfall and the leaf drainage volumes. Total rainfall energy is the sum of the energy of the rainfall that directly impacts the soil surface $\left(E(D T), \mathrm{J} \mathrm{m}^{-2}\right)$ and the energy of the 
rainfall that reaches the soil from leaves and branches after accounting for rainfall interception $\left(E(L D), \mathrm{J} \mathrm{m}^{-2}\right)$. The energy of leaf drainage is estimated as a function of the height of the plant canopy $(P H, \mathrm{~m})$ (Brandt 1990). Soil detachment by rainfall impact is estimated as a function of the soil detachability index $\left(K, \mathrm{~g} \mathrm{~J}^{-1}\right)$ and the total energy of the effective rainfall $\left(E E, \mathrm{~J} \mathrm{~m}^{-2}\right)$.

$$
\begin{aligned}
& E(D T)=D T K E=D T 35.9[1-0.559 \exp (-0.034 I)] \\
& E(L D)=\left(15.8 P H^{0.5}\right)-5.87 \\
& E E=E(D T)+E(L D) \\
& F=K E E 10^{-2}
\end{aligned}
$$

where $K E\left(\mathrm{~J} \mathrm{~m}^{-2} \mathrm{~mm}^{-1}\right)$ is the kinetic energy of the rain, and $I\left(\mathrm{~mm} \mathrm{~h}^{-1}\right)$ is rainfall intensity. The parameter soil detachability estimates the weight of the soil that is detached by a unit of rainfall energy and is estimated based on soil texture (Table 1). The energy of the rainfall that directly hits the soil surface only depends on the effective rainfall that reaches the soil as direct throughfall and the kinetic energy of the rain $\left(K E, \mathrm{~J} \mathrm{~m}^{-2} \mathrm{~mm}^{-1}\right)$. In this study, kinetic energy was calculated following the approach of Coutinho and Tomás (1995), which was developed in southern Portugal under Mediterranean conditions. Values of $E(L D)$ are negative when those of $P H$ are very low. In those cases, $E(L D)$ assumes a value of zero.

Soil detachment by runoff

The runoff volume per raster cell $(Q, \mathrm{~mm})$ is calculated using the average annual precipitation $(R, \mathrm{~mm})$, the critical value of soil moisture storage capacity $\left(R_{C}, \mathrm{~mm}\right)$, and the mean annual rainfall per erosive rain-day $\left(R_{0}, \mathrm{~mm}\right)$. An erosive rain-day is defined when a total rainfall volume $>12.7 \mathrm{~mm}$ or at least a peak intensity that is $>6.35 \mathrm{~mm}$ in 15 min is recorded in one day (Renard et al. 1997).

$$
\begin{aligned}
& Q=R \exp \left(\frac{-R_{C}}{R_{0}}\right) \\
& R_{C}=1000 \mathrm{MSBDVol} l_{\text {eff }} E H D\left(\frac{E T_{a}}{E T_{0}}\right)^{0.5}
\end{aligned}
$$

where $M S$ (\% on weight basis) is the soil moisture content at field capacity, $B D\left(\mathrm{Mg} \mathrm{m}^{-3}\right)$ is the bulk density of the soil, $\operatorname{Vol}_{\text {eff }}(0-1)$ is the effective volume of the soil, which is the ratio between the volume of the fine fraction $(<2 \mathrm{~mm})$ and the total volume of the soil (Soto and Navas 2004), EHD (m) is the effective hydrological depth, and $E T_{a} / E T_{0}(0-1)$ is the ratio between actual and potential evapotranspiration. The $E H D$ describes the depth 
within which the storage of water affects the generation of runoff. Runoff detaches soil particles as a function of runoff volume, soil resistance $\left(Z, \mathrm{kPa}^{-1}\right)$, slope steepness $(S$, radians), and the proportion of the surface covered $(G C, \%)$ :

$$
\begin{aligned}
& H=Z Q^{1.5} \sin S(1-G C) 10^{-2} \\
& Z=\frac{1}{0.5 C O H}
\end{aligned}
$$

where $\mathrm{COH}(\mathrm{kPa})$ is the soil surface cohesion at soil saturation conditions and its values are associated with the types of soil texture (Morgan 2001) (Table 1). $\mathrm{K}$ indices and $\mathrm{COH}$ parameters were determined experimentally for a wide range of soils for use in the European Soil Erosion Model (EUROSEM; Morgan et al. 1998).

Runoff transport capacity

The transport capacity of detached soil particles by runoff is calculated as a function of runoff volume, slope steepness, and the $C$ and $P$ factors of the Revised Universal Soil Loss Equation (RUSLE) (Renard et al. 1997). $C$ and $P$ account for the different covermanagement conditions and support practices, respectively.

$$
T C=C P Q^{2} \sin S 10^{-2}
$$

Although the $T C$ factor accounts for the ability of runoff to move detached soil particles by splash or runoff, it cannot be used to calculate the travel time or distance of eroded soil particles down slope; hence, a specific model of sediment delivery ratio is necessary to account for those processes.

\section{The SEDD model of sediment delivery and yield}

The SEDD model discretizes a watershed into morphological units and calculates the sediment delivery ratio in each unit (Ferro and Porto 2000). In a spatially distributed approach, each cell $i$ of the catchment is considered a morphological unit (areas of defined aspect, length, and steepness). In modelling the within-basin variability of the hillslope sediment delivery processes, the sediment delivery ratio for cell $i\left(S D R_{i}\right)$ is the fraction of the gross soil loss from cell $i$ that reaches a flow pathway that is a continuous stream system or a change in steepness or slope aspect. The $S D R_{i}$ was estimated as a function of travel time $\left(t_{i}\right.$, s) (Ferro and Minacapilli 1995; Ferro 1997).

$$
\begin{aligned}
& S D R_{i}=\exp \left(-\beta t_{i}\right) \\
& t_{i}=\sum_{i=1}^{N_{p}} \frac{l_{i}}{v_{i}}
\end{aligned}
$$




$$
v_{i}=d_{i} s_{i}^{0.5}
$$

where $\beta$ is the catchment-specific parameter, which primarily depends on watershed morphology and is assumed constant for a given basin, $N_{p}$ is the number of cells through which the flow path traverses from cell $i$ to the channel, $l_{i}(\mathrm{~m})$ is the length of segment $i$ in the flow path and is equal to the side or diagonal of a cell depending on the flow direction in the cell, $v_{i}\left(\mathrm{~m} \mathrm{~s}^{-1}\right)$ is the flow velocity, $d_{i}\left(\mathrm{~m} \mathrm{~s}^{-1}\right)$ is a coefficient that is a measure of surface roughness characteristics, and $s_{i}\left(\mathrm{~m} \mathrm{~m}^{-1}\right)$ is the slope of cell $i$. Equation (16) is derived from Manning's Equation and the $d_{i}$ coefficient of each grid cell is influenced by land cover and the effect is measured by the value of Manning's Roughness Coefficient and the hydraulic radius (Fu et al. 2006).

To estimate $\beta$, Fernandez et al. (2003) used inverse modelling in Idaho (USA), and Jain and Kothyari (2000) tested $\beta$ between 0.1 and 1.6 with an increment of 0.1 and found that sediment yield was not very sensitive to the value of $\beta$. In this study, we assumed that $\beta=1$, as did Fu et al. (2006) when modelling sediment yield using the RUSLE and the SEDD models in Washington State (USA). We calculated the Sediment Delivery Ratio for each pixel $\left(S D R_{i}\right)$ and the average $S D R$ for each endorheic sub-catchment $\left(S D R_{W}\right)$. A wide range of geomorphological, hydrological, environmental, and basin factors influences the magnitude of the $S D R_{W}$ in a particular catchment.

We assumed that $S D R$ is time-dependant only and, over a long period, an ephemeral or permanent stream must transport to the outlet all of the sediment that is delivered to it. The sediment yield for each cell $i\left(S Y_{i}, \mathrm{Mg} \mathrm{ha}^{-1} \mathrm{yr}^{-1}\right)$ is estimated using values of gross soil erosion obtained by the RMMF model and the map of $S D R_{i}$.

$$
S Y_{i}=S D R_{i} E_{i}
$$

The sediment transport efficiency of a catchment decreases as $t_{i}$ increases and, therefore, as catchment area $\left(A_{w}\right.$, ha) increases. The annual intra-basin stored sediment $\left(I S S_{W}, \%\right)$ is the amount of total sediment that temporally accumulates in the basin during the year and does not reach the basin outlet (Beach 1994). For a better assessment of the processes of soil redistribution in the study area, $I S S_{W}$ was calculated as the proportion of the total eroded particles in each sub-catchment $\left(E_{W T}\right)$ that temporally accumulated in the basin:

$$
I S S_{W}=100-\left(\frac{100 S Y_{W}}{E_{W T}}\right)
$$

Data collection 
To calculate annual precipitation, we used the daily rainfall data recorded at the Estaña Weather Station in the period 1993-2006, but to calculate the average rainfall intensity ( $I$ $\left.=15.1 \mathrm{~mm} \mathrm{~h}^{-1}\right)$ and the mean annual rainfall per erosive rain-day $\left(R_{0}=35.9 \mathrm{~mm}\right)$, we used rainfall data recorded at 15-min intervals at the Canelles Weather Station for the period 1997-2006. The Canelles Weather Station is located $9 \mathrm{~km}$ south-eastern of the study area. The size of the catchment and the range in elevation were small; therefore, rainfall parameters were assumed to apply to the entire catchment. Values of rainfall interception $(A)$, canopy cover $(C C)$, plant height $(P H)$, and the ratio between actual and potential evapotranspiration are those proposed for the land uses in the study area (López-Vicente 2008). Values of $A, C C$, and $P H$ were based on annual averages because most of the shrubs and trees (e.g., holm oak) in the area were perennials and their canopy structures changed little throughout the year. Values of surface roughness correspond to those selected by Haan et al. (1994) for different types of land uses. The values of effective hydrological depth for the different soil types in the catchment (range $=0.00 \mathrm{~m}-0.25 \mathrm{~m}$ ) were from Machín et al. (2008), and the maps of soil properties were derived at a spatial resolution of $5 \times 5 \mathrm{~m}$.

A field survey collected 227 soil samples following a regular net of $100 \mathrm{~m} \mathrm{x} 100 \mathrm{~m}$. We measured bulk density, stoniness, the contents of sand, silt, and clay, and soil moisture content at field capacity, and estimated soil detachability and soil cohesion. Slope steepness and slope length were calculated using a Digital Elevation Model (DEM) of the study area (López-Vicente et al. 2009), which was based on a commercial DEM, and modified accounting elevation data measured using a total topographic station, GPS, and field observations. The enhanced DEM matched the geomorphic features of the study area. The values of the $C$ and $P$ factors of the RUSLE model were those estimated by López-Vicente and Navas (2009), who followed the guide of the RUSLE model proposed by Renard et al. (1997).

Before running the RMMF model, a mask associated with the gullies was created within a GIS and the values of $A, C C, G C, E H D, E T_{a} / E T_{0}$, and $C-R U S L E$ were set to equal those proposed for areas without vegetation cover. The mask was intended to correct for the special conditions of the soil cover in the gullies, where there was almost no protection and the soil surface was directly affected by splash and runoff. The maps of the parameters were created with the aid of the Splines Interpolator Method, which fits a minimum-curvature surface through the input points. That method is based on a family of continuous, regular, and derivable functions. Splines are similar to the equations obtained 
from trend surfaces or regression-based methods and this method creates a new function for each location or sampling point, without a loss of continuity properties among the curves (Mitasova et al. 1995) and, therefore, is adequate for mapping soil properties.

The travel times for each of the $N_{p}$ cells in equation (15) were calculated using the Sediment Yield Tools 1.03 extension in ArcView GIS 3.2 (Schäuble 2005). All of the maps, interpolations, and mathematical operations were performed using ArcView GIS 3.2 and $\operatorname{ArcGIS} 9.1$ applications at a spatial resolution of $5 \mathrm{~m}$ x $5 \mathrm{~m}$. Finally, a simplified map of the geomorphic elements (gullies, slopes, and depositional elements) was generated based on the geomorphologic map of the Estaña Catchment (López-Vicente et al. 2009).

\section{Results}

\section{Runoff and soil erosion}

In the Estaña Catchment, north-eastern Spain, the average effective rainfall was $486 \mathrm{~mm}$ (82\% of the annual precipitation). Rainfall volume was split between leaf drainage (mean volume $=236 \mathrm{~mm})$ and direct throughfall rainfall $($ mean volume $=250 \mathrm{~mm})$. The average energy of the direct throughfall rainfall was $5970.1 \mathrm{~J} \mathrm{~m}^{-2}[99.7 \%$ of the total effective energy of the rain $\left(\right.$ mean value $\left.=5985.5 \mathrm{~J} \mathrm{~m}^{-2}\right)$ ]. The average soil detachment by splash at the Estaña Catchment was $52.7 \mathrm{Mg} \mathrm{ha}^{-1} \mathrm{yr}^{-1}$, with values $>100 \mathrm{Mg} \mathrm{ha}^{-1} \mathrm{yr}^{-1}$ in gullies and paths (Fig. 2a). The average soil moisture storage capacity was $19.7 \mathrm{~mm}$ and average overland flow per raster cell was $350 \mathrm{~mm}$ (range $=137 \mathrm{~mm}$ in areas that had high vegetation cover to $595 \mathrm{~mm}$ in areas of bare soil). Mean soil detachment by runoff was 5.2 $\mathrm{Mg} \mathrm{ha}^{-1} \mathrm{yr}^{-1}$ (range $=0.0-52.9 \mathrm{Mg} \mathrm{ha}^{-1} \mathrm{yr}^{-1}$ ) (Fig. 2b).

Average total soil detachment was $57.9 \mathrm{Mg} \mathrm{ha}^{-1} \mathrm{yr}^{-1}$ and values were highest in the gullies, paths, and cultivated and non-cultivated steep areas (average rates $>100 \mathrm{Mg} \mathrm{ha}^{-1}$ $\mathrm{yr}^{-1}$ ). The lowest rates were in pastures and bank vegetation (average rates $<2 \mathrm{Mg} \mathrm{ha}^{-1} \mathrm{yr}^{-}$ ${ }^{1}$ ). Areas that had steep slopes and low effective hydrological depth had the highest rates of soil detachment. The RMMF model predicted no erosion on flat areas, which covered $0.6 \%$ of the catchment. The map of total soil detachment indicated a bimodal distribution, which was associated with the difference in the magnitude of soil detachment by splash (91\% of total soil detachment) and by runoff (Fig. 2c).

In the Estaña Catchment, the average transport capacity of runoff, $T C$ in equation (13), was 16.8 $\mathrm{Mg} \mathrm{ha}^{-1} \mathrm{yr}^{-1}$, with values $>100 \mathrm{Mg} \mathrm{ha}^{-1} \mathrm{yr}^{-1}$ in gullies and paths and $>40 \mathrm{Mg} \mathrm{ha}^{-1}$ $\mathrm{yr}^{-1}$ in steep cultivated and uncultivated areas (Fig. 2d). Land uses that had high canopy and surface cover had the lowest $T C$. 
The RMMF model estimated that the average erosion rate in the entire catchment was 11.9 $\mathrm{Mg} \mathrm{ha}^{-1} \mathrm{yr}^{-1}$, and was as high as $170.3 \mathrm{Mg} \mathrm{ha}^{-1} \mathrm{yr}^{-1}$ within a raster cell in a very steep area in a gully (Fig. 3a). The land uses of paths, areas of bare soil, crops, orchards, open Mediterranean forests, and dispersed scrublands were the erosive-type and had mean erosion rates that were higher than the tolerable erosion rate $\left(T=6 \mathrm{Mg} \mathrm{ha}^{-1} \mathrm{yr}^{-1}\right)$ for Mediterranean soils (De la Horra 1992). Moreover, the average erosion rate in cultivated lands (18.8 $\mathrm{Mg} \mathrm{ha}^{-1} \mathrm{yr}^{-1}$ ) was much higher than the average value in rangelands (7.1 Mg $\mathrm{ha}^{-1} \mathrm{yr}^{-1}$ ) (Table 2). Thus soil erosion was negatively correlated with rainfall interception, canopy cover, and ground cover, and positively correlated with slope steepness. Urban areas and those covered by boulder grounds had no soil and, therefore, no soil erosion.

The simplified geomorphic map of the Estaña Catchment included gullies, steep and medium slopes developed over Keüper and Muschelkalk Facies as erosive-type geoforms, and doline, alluvial, colluvial, and valley floor deposits (Fig. 4). Steep slopes were those that had a slope steepness $>22.5 \%$ (Morgan 2005), which covered 33\% of the catchment area. Gullies had the highest values of soil erosion (mean $=133 \mathrm{Mg} \mathrm{ha}^{-1} \mathrm{yr}^{-1}$ and maximum $=170 \mathrm{Mg} \mathrm{ha}{ }^{-1} \mathrm{yr}^{-1}$ ) that corresponded to irreversible processes of soil degradation (Fig. 5) (Table 3). The soils developed on slopes on Keüper Facies had erosion rates that were 59\% higher than those on Muschelkalk Facies, which reflected the higher erodibility of their parent material (Fig. 5) (Table 3). Those results agree with field observations of gullies and rills that were mainly developed on clays and marls.

The maximum values of soil erosion in hillslopes exceeded $140 \mathrm{Mg} \mathrm{ha}^{-1} \mathrm{yr}^{-1}$, whereas the maximum values predicted for doline, alluvial, colluvial, and valley floor deposits ranged between 39 and $56 \mathrm{Mg} \mathrm{ha}^{-1} \mathrm{yr}^{-1}$; however, estimated mean erosion rates for hillslopes and depositional elements were similar (7 - $14 \mathrm{Mg} \mathrm{ha}^{-1} \mathrm{yr}^{-1}$ ) (Table 3). The average erosion rates in erosive-type and deposition-type geomorphic features were 12.1 $\mathrm{Mg} \mathrm{ha}^{-1} \mathrm{yr}^{-1}$ and 9.9 $\mathrm{Mg} \mathrm{ha}^{-1} \mathrm{yr}^{-1}$, respectively.

After studying splash and runoff detachment of soils in cultivated areas in the Estaña Catchment, López-Vicente et al. (2008b) quantified soil loss using ${ }^{137}$ Cs at several control points. Six control points were in depositional elements and were compared to the model's predictions (Fig. 4). The average erosion rates derived from ${ }^{137} \mathrm{Cs}$ and those predicted by the RMMF model were 6.1 and $9.7 \mathrm{Mg} \mathrm{ha}^{-1} \mathrm{yr}^{-1}$, respectively. Both the estimated and quantified erosion rates in valley floor and colluvial deposits were similar, whereas the erosion rates at two of the four control points in doline deposits were more variable. Those results confirm the existence of processes of soil erosion in the Holocene depositional- 
type elements and suggest the enforcement of the erosive dynamic from depositional processes toward a more erosive context. The shift was caused by changes in land use that strongly affected the processes of soil loss. Cultivation of the land is a major factor in soil erosion in similar environments (Navas et al. 2007; Quine et al. 1994) and other agricultural areas (Fu et al. 2006).

In the Estaña Catchment, severe erosion ( $>40 \mathrm{Mg} \mathrm{ha}^{-1} \mathrm{yr}^{-1}$ ) occurred in $5.5 \%$ of the area, and $1.2 \%$ of the area had no erosion. Erosion rates $>40 \mathrm{Mg} \mathrm{ha}^{-1} \mathrm{yr}^{-1}$ are associated with processes of intense land degradation, such as has occurred in cultivated plots in the catchment (Soto and Navas 2008). The estimated total amount of eroded soil in the catchment was $2712 \mathrm{Mg} \mathrm{yr}^{-1}$, and average erosion rates in the 15 sub-catchments $\left(E_{W}\right)$ were positively correlated with catchment area $\left(A_{W}\right)$ (ranging $=0.1-13.4 \mathrm{Mg} \mathrm{ha}^{-1} \mathrm{yr}^{-1}$ ) and were negatively correlated with the proportion of the catchment area covered with forest and scrublands $\left(A_{W}-N a t\right)$ (Fig. 3b, c).

\section{Sediment delivery ratio and sediment yield}

Flow velocity of the surface runoff per raster cell $\left(v_{i}\right)$ was calculated using equation (16) and the corresponding map was generated in GIS (Fig. 6a). The highest estimated velocity of overland flow was in gullies $\left(3.1 \mathrm{~m} \mathrm{~s}^{-1}\right)$ and the mean velocity in the catchment was 0.7 $\mathrm{m} \mathrm{s}^{-1}$. The average sediment delivery ratio $(S D R)$ in the Estaña Catchment was 0.41. Although the highest values of $v_{i}$ were on steep slopes and in areas that had limited vegetation cover, the $S D R$ was strongly influenced by the flow length in accordance with equation (15). The highest values of $S D R$ (1.0) were in the pixels that represented the area surrounding the lakes and those in the sinks of the endorheic sub-catchments (Fig. 6b).

The SDRs (range $=0.94-0.29)$ of the sub-catchments $\left(S D R_{W}\right)$ were negatively correlated with catchment area $\left(A_{W}\right)$ and the length of the main stream of the catchment $\left(M S L_{W}\right)$ (Fig. 6c, d). The correlation between $S D R_{W}$ and $A_{W}$ was logarithmic and the relationship for our catchment has been observed elsewhere (e.g. Vanoni 1975; Bagarello et al. 1991).

The estimated mean sediment yield $(S Y)$ in the study area was $4.8 \mathrm{Mg} \mathrm{ha}^{-1} \mathrm{yr}^{-1}$ and reached values $>100 \mathrm{Mg} \mathrm{ha}^{-1} \mathrm{yr}^{-1}$ in some sections of the gullies and in steep slopes that were close to the lakes and the sinks of the dolines. The spatial distribution of the estimated values reflected the efficiency of hillslopes and ephemeral streams near the lakes in transferring the eroded soil into the water bodies (Fig. 7a). The total sediment exported to the lakes and sinks of the dolines was $1106 \mathrm{Mg} \mathrm{yr}^{-1}$; thus, 59.2\% of the annual 
eroded soil was stored within the catchment downslope $\left(I S S_{W}\right)$ from the eroding source area and will reach the lakes and sinks in coming years.

The average sediment yield $\left(S Y_{W}\right)$ at the catchment scale and the proportion of the catchment that was covered by forest and scrublands were negatively correlated (Fig. 7b). The proportion of intra-basin stored sediment $\left(I S S_{W}\right)$ and catchment area $\left(A_{W}\right)$ were positively correlated (Fig. 7c). Moreover, the small sub-catchments in the Estaña Catchment had high values of $S D R_{W}$ and high proportions of natural vegetation.

\section{Discussion}

In the Estaña Catchment, north-eastern Spain, the predicted splash erosion rates were much higher than was runoff erosion because the RMMF model does not incorporate the effect of cumulative overland flow (Fig. 2c). Therefore, soil detachment by runoff might have been underestimated, especially in the gullies, where runoff was concentrated. Moreover, runoff transport capacity was the limiting factor in estimating soil erosion (96.9\%) in the catchment surface. At regional or basin scales, the accurate assessment of runoff transport capacity and the estimation of how the amount and size of eroded particles delivered into the runoff modify its erosive and transport capabilities are required (Gabet and Sternberg 2008). Nevertheless, that disadvantage was not critical in modelling soil detachment and transport processes in the Estaña Catchment because of the relative small size of the study area and of the lack of a river or another permanent water channel.

Estimated erosion rates in gullies were within the range of values reported by Benito et al. (1992) in badlands close to the southern limit of the External Ranges of the Pyrenees and measured with microtopographic profiles (erosion rates of $24 \mathrm{Mg} \mathrm{ha}^{-1}$ and $485 \mathrm{Mg} \mathrm{ha}^{-}$

${ }^{1}$ for period of seven and 15 months, respectively). De Santisteban et al. (2006), who measured rill and gully erosion in crops and vineyards in central Navarre, NE Spain, where the physiographical characteristics and rainfall are similar to those in the Estaña Catchment, reported mean values from 2 to $162 \mathrm{Mg} \mathrm{ha}^{-1} \mathrm{yr}^{-1}$. In the Estaña Catchment, the estimated erosion rates in gullies were higher than the rates in gullies developed over Miocene marls in southern Navarre, NE Spain (mean $=27 \mathrm{Mg} \mathrm{ha}^{-1} \mathrm{yr}^{-1}$ ) (Casalí et al. 1999) and in the clay and marls of the Central Ebro Valley measured with erosion pins (mean $=25 \pm 13 \mathrm{Mg} \mathrm{ha}^{-1} \mathrm{yr}^{-1}$ ) (Desir and Marín 2007). Differences among studies might have been due to the higher volume of precipitation in the Estaña Catchment.

The small difference in erosion rates between erosive-type and deposition-type geomorphic features was influenced by the high proportion of the area covered by crops 
and orchards in the depositional geomorphic elements and the high proportion of forests and scrublands on hillslopes (Table 3). The similarity of the erosion rates quantified using ${ }^{137} \mathrm{Cs}$ and those estimated in depositional-type geoforms reflects the reliability of the proposed estimation procedure and suggests that the RMMF and SEDD models are appropriate for ungauged basins.

In our study, the estimates of soil loss reflect the influence of land use on the magnitude of soil erosion, e.g., in old fields, recently abandoned fields, crops, and pastures at the field scale in the Estaña Catchment (López-Vicente et al. 2008b). In the Eastern Rif of Morocco, where crops were the most erosion-sensitive land use in complex landscapes, estimates of soil loss based on ${ }^{137}$ Cs measurements (Sadiki et al. 2007) were similar to those found in the Estaña Catchment. In addition, Navas et al. (2005) used ${ }^{137} \mathrm{Cs}$ to measure soil loss in mountains of the Central Pyrenees, where the rates of mobilization in the soils of scrublands were higher than they were in the soils developed on forested slopes.

In the Estaña Catchment, total sediment yield and intra-basin stored sediments underscored the importance of including endorheic areas when assessing the total sediment budget at basin and regional scales. The estimated proportion of $I S S_{W}$ in the Estaña Catchment was similar to that observed by Renwick et al. (2005a) in the USA, where the total sedimentation in impoundments was 18 to $74 \%$ of the total sheet and rill erosion.

The high sediment yields in the cultivated dolines and valley floors in the Estaña Catchment were similar to those reported by Parsons et al. (2006), who found that most of the sediment transported by ephemeral or permanent streams was from deposits near the streams within a catchment. However, the reed grass surrounding the Estaña lakes had high trap efficiency (TE), which reduced drastically the amount of sediments that reached the lakes. That process has been observed on an ongoing research in the Estaña Catchment, where the ${ }^{137} \mathrm{Cs}$ profiles indicated sediment accumulation rates of $1 \mathrm{~cm} \mathrm{yr}^{-1}$ in the reed grass around the lakes (Navas, personal communication, 2008). Future research should investigate the effect of plant architecture on soil erosion and deposition processes (Morgan and Duzant 2008), especially the role of the vegetation on the banks of lakes in controlling the amount of sediment that reaches the lakes and the retention capacity of the topography, especially in gentle areas (Schäuble et al. 2008).

In the Estaña Catchment, the high estimated $S D R_{i}$ and $S Y_{i}$ in the doline and valley floor deposits were influenced by their proximity to the sinks of the endorheic sub- 
catchments (Table 3). As expected given their spatial location, the upper and middle sections of the slopes and gullies had low $S D R_{i}$ and $S Y_{i}$. Gullies had high intra-basin stored sediments $\left(I S S_{i}\right)$, which indicated that streams did not transport all of the sediment that was supplied to them, as was the case described by Parsons et al. (2006). In our study, the estimated sediment yields and intra-basin stored sediments of the geoforms (Table 3) indicated that the most significant sources of sediments into the Estaña lakes were those nearest to the water bodies and those close to the main flow paths, even though erosion rates were higher in gullies and on steep slopes.

The high proportions of intra-basin stored sediments calculated for the different erosive and deposition-type geoforms indicated that erosion and deposition processes occurred simultaneously among the different geoforms in the study area (Table 3). Those simultaneous processes were evident in an earlier study of soil erosion and deposition that used ${ }^{137}$ Cs on slope transects within the Estaña Catchment (Soto and Navas 2008). Further improvements in modelling sediment delivery may consider rates of $S D R_{i}>1.0$ in some years and during high-intense episodes of rainfall.

The high density of gullies within the large sub-catchments and the high proportion of cultivated areas within the largest sub-catchments, which experienced intense soil erosion, influenced significantly the correlations between average erosion rate and catchment area (positive) and the proportion of the area covered by natural vegetation (negative). The positive correlation between intra-basin stored sediment $\left(I S S_{W}\right)$ and catchment area $\left(A_{W}\right)$ occurred because, during transport through streams, more sediment is progressively trapped in footslopes, concavities, alluvial plains, and other sinks. In a siltation reservoir in Romania, where catchment area and geomorphology conditions controlled sediment yields, the results were similar to ours (Rãdoane and Rãdoane 2005). In the USA, land use explained most of the variation in sediment yields in different areas (Renwick et al. 2005b). Collectively, those results emphasize the spatial and temporal dependence of the processes of sediment delivery and yield. The time-dependence of the process of sediment yield explains the high estimated $I S S_{i}$ in the gullies of the Estaña Catchment, northern Spain (Table 3).

\section{Conclusions}

The RMMF and SEDD models and a detailed database in a GIS framework allowed us to create spatially distributed maps of soil erosion, sediment delivery, and sediment yield in small- and medium-sized catchments. In the Estaña Catchment, northern Spain, the 
average erosion rate was higher than the tolerable rate of soil loss for Mediterranean soils, which indicates that the current scenario of land degradation is a serious threat to the preservation of soil and water resources.

The highest erosion rates were predicted in gullies, where the mean and maximum rates indicated irreversible processes of soil loss. Soils that developed on slopes had maximum erosion rates that were similar to those in gullies, but mean rates were much lower on slopes. Slopes on Keüper Facies had mean erosion rates that were higher than the rates on Muschelkalk Facies because the erodibility of clays and marls is higher than the erodibility of limestones.

Soils in dolines and valley floors covered by crops had high rates of erosion and sediment yield. The planting of crops on steep slopes and near gullies promoted an increase in soil erosion rates. The RMMF and SEDD models revealed the important role played by human-induced changes in vegetation and soil parameters in increases in the rate of soil erosion.

In the Estaña Catchment, sediment delivery ratio was strongly influenced by the travel times of soil particles and was less sensitive to the type of land use. The map of estimated sediment yields indicated the importance of the distance between the erosion site and the outlet. The high estimated proportions of intra-basin stored sediment in the 15 subcatchments indicated the importance of the processes of maximum transport capacity by runoff, trap efficiency by streams and vegetation, and channel erosion and delivery processes, which should be incorporated into future research. Deposition geoforms are consequences of medium- and long-term geomorphic processes of soil loss and intra-basin storage. The estimated soil erosion, sediment yields, and intra-basin stored sediments in the geoforms suggested that soil erosion and deposition occur simultaneously within the different geoforms.

In the Estaña Catchment, average soil erosion rates and catchment size were positively correlated, whereas sediment delivery ratios and sediment yields were negatively correlated with catchment size, the length of the main stream of the catchment, and the proportion of the area that was covered with forests and scrublands.

The combination of the RMMF model and the SEDD model has the potential to interpret the processes of soil erosion and deposition in the short-term and can increase the understanding of how the cultivation of the land affects the dynamics of soil erosion and sediment delivery in complex catchments. The procedure could be used in ungauged 
catchments to identify the main source areas of eroded particles and to assess changes in the intensity of the erosive dynamic that affects geomorphic elements in the short-term.

Acknowledgements This research was financially supported by the following project: "Soil erosion and carbon dynamic in Mediterranean agroecosystems: radioisotopic modelling at different spatial and temporal scales" (MEDEROCAR, CGL2008-00831/BTE) funded by the Spanish Ministry of Science and Innovation.

\section{References}

Bagarello V, Ferro V, Giordano G (1991) Contributo alla valutazione del fattore di deflusso di Williams e del coefficiente di resa solida per alcuni bacini idrografici siciliani. Rivista di Ingegneria Agraria 4: 238-251.

Beach T (1994) The fate of eroded soil: sediment sinks and sediment budgets of agrarian landscapes in southern Minnesota, 1851-1988. Annals of the Association of American Geographers 84: 5-28.

Benito G, Gutiérrez M, Sancho C (1992) Erosion Rates in Badland Areas of the Central Ebro Basin (NE-Spain). Catena 19: 269-286.

Brandt CJ (1990) Simulation of the size distribution and erosivity of raindrops and throughfall drops. Earth Surface Processes and Landforms 15: 687-698.

Casalí J, López JJ, Giráldez JV (1999) Ephemeral gully erosion in southern Navarra (Spain). Catena 36: 65-84.

Coutinho MA, Tomás PP (1995) Characterization of raindrop size distributions at the Vale Formoso Experimental Erosion Center. Catena 25(1-4): 187-197.

De la Horra JL (1992) Aspectos biogeográficos en relación con la problemática agraria de la comarca de Torrijos (Toledo) (Biogeographic aspects in relation with the problemmatic agricultura in Torrijos). Doctoral Thesis. Universidad Complutense de Madrid: Madrid, Spain.

de Moor JJW, Verstraeten G (2008) Alluvial and colluvial sediment storage in the Geul River catchment (The Netherlands) - Combining field and modelling data to construct a Late Holocene sediment budget. Geomorphology 95(3-4): 487-503.

De Roo APJ, Wesseling CG, Ritsema CJ (1996) LISEM: a single-event physically based hydrological and soil erosion model for drainage basins: I: theory, input and output. Hydrological Processes 10: 1107-1117.

De Santisteban LM, Casalí J, López JJ (2006) Assessing soil erosion rates in cultivated areas of Navarre (Spain). Earth Surface Processes and Landforms 31: 487-506. 
de Vente J, Poesen J, Arabkhedri M, Verstraeten G (2007) The sediment delivery problem revisited. Progress in Physical Geography 31(2): 155-178.

de Vente J, Poesen J, Verstraeten G, Van Rompaey A, Govers G (2008) Spatially distributed modelling of soil erosion and sediment yield at regional scales in Spain. Global and Planetary Change 60: 393-415.

Desir G, Marín C (2007) Factors controlling the erosion rates in a semi-arid zone (Bardenas Reales, NE Spain). Catena 71(1): 31-40.

Di Piazza GV, Di Stafano C, Ferro V (2007) Modelling the effects of a bushfire on erosion in a Mediterranean basin. Hydrological Sciences Journal 52(6): 1253-1270.

Di Stefano C, Ferro V (2007) Evaluation of the SEDD model for predicting sediment yield at the Sicilian experimental SPA2 basin. Earth Surface Processes and Landforms 32(7): 1094-1109.

Fernandez C, Wu JQ, McCool DK, Stöckle CO (2003) Estimating water erosion and sediment yield with GIS, RUSLE, and SEDD. Journal of Soil and Water Conservation 58(3): 128-136.

Ferro V (1997) Further remarks on a distributed approach to sediment delivery. Hydrological Sciences Journal - Journal des Sciences Hydrologiques 42(5): 633-647.

Ferro V, Minacapilli M (1995) Sediment delivery processes at basin scale. Hydrological Sciences Journal - Journal des Sciences Hydrologiques 40: 703-717.

Ferro V, Porto P (2000) Sediment delivery distributed (SEDD) model. Journal of Hydrologic Engineering 5(4): 411-422.

Fu G, Chen S, McCool DK (2006) Modeling the impacts of no-till practice on soil erosion and sediment yield with RUSLE, SEDD, and ArcView GIS. Soil \& Tillage Research 85: 38-49.

Gabet EJ, Sternberg P (2008) The effects of vegetative ash on infiltration capacity, sediment transport, and the generation of progressively bulked debris flows. Geomorphology 101(4): 666-673.

González-Hidalgo JC, Peña-Monné JL, de Luis M (2007) A review of daily soil erosion in Western Mediterranean areas. Catena 71(2): 193-199.

Haan CT, Barfield BJ, Hayes JC (1994) Design Hydrology and Sedimentology for Small Catchments. Academic Press: San Diego, California.

Hessel R, Jetten V (2007) Suitability of transport equations in modelling soil erosion for a small Loess Plateau catchment. Engineering Geology 91(1): 56-71.

Hunt CO, Gilbertson DD, El-Rishi HA (2007) An 8000-year history of landscape, climate, and copper exploitation in the Middle East: the Wadi Faynan and the Wadi Dana National Reserve in southern Jordan. Journal of Archaeological Science 34(8): 1306-1338.

Hunt AG, Wu JQ (2004) Climatic influences on Holocene variations in soil erosion rates on a small hill in the Mojave Desert. Geomorphology 58: 263-289.

Jain MK, Kothyari UC (2000) Estimation of soil erosion and sediment yield using GIS. Hydrological Sciences Journal - Journal des Sciences Hydrologiques 45(5): 771-786. 
López-Vicente M (2008) Erosión y redistribución del suelo en agroecosistemas mediterráneos: Modelización predictiva mediante SIG y validación con ${ }^{137}$ Cs (Cuenca de Estaña, Pirineo Central) / Soil erosion and redistribution in Mediterranean agro-ecosystems: predictive modelling with GIS and validation with ${ }^{137} \mathrm{Cs}$ (Estaña Catchment, Spanish Central Pyrenees). University of Zaragoza: Zaragoza, Spain; 212 pp. ISBN: 978-84-7733-008-0.

López-Vicente M, Navas A (2009) Predicting soil erosion with RUSLE in Mediterranean agricultural systems at catchment scale. Soil science 174(5): 272-282.

López-Vicente M, Navas A, Machín J (2008a) Identifying erosive periods by using RUSLE factors in mountain fields of the Central Spanish Pyrenees. Hydrology and Earth System Science 12(2): 523-535.

López-Vicente M, Navas A, Machín J (2008b) Modelling soil detachment rates in rainfed agrosystems in the south-central Pyrenees. Agricultural Water Management 95(9): 1079-1089.

López-Vicente M, Navas A, Machín J (2009) Geomorphic mapping in endorheic catchments in the Spanish Pyrenees: an integrated GIS analysis of karstic features. Geomorphology 111(1-2), 38-47.

Machín J, López-Vicente M, Navas A (2008) Cartografía digital de suelos de la Cuenca de Estaña (Prepirineo Central) / Digital soil mapping of the Estaña Catchment (Spanish Central PrePyrenees). Proceedings of X Reunión Nacional de Geomorfología, Cádiz, Spain.

Mitasova H, Mitas L, Brown WM, Gerdes DP, Kosinovsky I, Baker T (1995) Modelling spatially and temporally distributed phenomena: new methods and tools for GRASS GIS. International Journal of Geographic Information Systems 9(4): 433-446.

Morgan RPC (2001) A simple approach to soil loss prediction: a revised Morgan-Morgan-Finney model. Catena 44(4): 305-322.

Morgan RPC (2005) Soil Erosion and Conservation. Third Edition. Blackwell Publishing Ltd, Oxford, United Kingdom.

Morgan RPC, Quinton JN, Smith RE, Govers G, Poesen JWA, Auerswald K, Chisci G, Torri D, Styczen ME (1998) The European Soil Erosion Model (EUROSEM): a dynamic approach for predicting sediment transport from fields and small catchments. Earth Surface Processes and Landforms 23(6): 527-544.

Morgan RPC, Duzant JH (2008) Modified MMF (Morgan-Morgan-Finney) model for evaluating effects of crops and vegetation cover on soil erosion. Earth Surface Processes and Landforms 33(1): 90-106.

Navas A, Machín J, Soto J (2005) Assessing soil erosion in a Pyrenean mountain catchment using GIS and fallout ${ }^{137}$ Cs. Agriculture, Ecosystems and Environment 105: 493-506.

Navas A, Walling DE, Quine T, Machín J, Soto J, Domenech S, López-Vicente M (2007) Journal of Radioanalytical and Nuclear Chemistry 274(2): 331-339. 
O'Farrell CR, Heimsath AM, Kaste JM (2007) Quantifying hillslope erosion rates and processes for a coastal California landscape over varying timescales. Earth Surface Processes and Landforms 32(4): 544-560.

Parsons AJ, Wainwright J, Brazier RE, Powell DM (2006) Is sediment delivery a fallacy? Earth Surface Processes and Landforms 31(10): 1325-1328.

Pelacani S, Märker M, Rodolfi G (2008) Simulation of soil erosion and deposition in a changing land use: A modelling approach to implement the support practice factor. Geomorphology 99(1-4): 329-340.

Quine T, Navas A, Walling DE, Machín J (1994) Soil erosion and redistribution on cultivated and uncultivated land near Las Bardenas in the Central Ebro River basin, Spain. Land Degradation and Rehabilitation 5(1): 41-55.

Rãdoane M, Rãdoane N (2005) Dams, sediment sources and reservoir silting in Romania. Geomorphology 71: 112-125.

Renard KG, Foster GR, Weesies GA, McCool DK, Yoder DC (1997) Predicting Soil Erosion by Water: A Guide to Conservation Planning with the Revised Universal Soil Loss Equation (RUSLE). Handbook \#703. US Department of Agriculture, Washington, DC.

Renwick WH, Smith SV, Bartley JD, Buddemeier RW (2005a) The role of impoundments in the sediment budget of the conterminous United States. Geomorphology 71(1-2): 99-111.

Renwick WH, Carlson KJ, Hayes-Bohanan JK (2005b) Trends in recent reservoir sedimentation rates in southwestern Ohio. Journal of Soil and Water Conservation 60(2): 72-79.

Sadiki A, Faleh A, Navas A, Bouhlassa S (2007) Assessing soil erosion and control factors by the radiometric technique in the Boussouab catchment, Eastern Rif, Morocco. Catena 71(1): 1320.

Sancho Marcén C (1988) El Polje de Saganta (Sierras Exteriores Pirenaicas, Prov. de Huesca). Cuaternario y Geomorfología 2(1-4): 107-113.

Schäuble H (2005) Sedimentfrachtprognosen mit GIS - Neue Strategien für globale Modellgleichungen unter besonderer Berücksichtigung von Staudämmen und des zeitlichen Wandels. Dissertation. Institut für Angewandte Geowissenschften, Technische Universität Darmstadt, Darmstadt, Germany.

Schäuble H, Marinoni O, Hinderer M (2008) A GIS-based method to calculate flow accumulation by considering dams and their specific operation time. Computers \& Geosciences 34(6): 635646.

Scholz G, Quinton JN, Strauss P (2008) Soil erosion from sugar beet in Central Europe in response to climate change induced seasonal precipitation variations. Catena 72(1): 91-105.

Soto J, Navas A (2004) A model of ${ }^{137}$ Cs activity profile for soil erosion studies in uncultivated soils of Mediterranean environments. Journal of Arid Environments 59: 719-730. 
Soto J, Navas A (2008) A simple model of Cs-137 profile to estimate soil redistribution in cultivated stony soils. Radiation Measurements 43(7): 1285-1293.

Svorin J (2003) A test of three soil erosion models incorporated into a geographical information system. Hydrological Processes 17: 967-977.

Van Rompaey A, Verstraeten G, Van Oost K, Govers G, Poesen J (2001) Modelling mean annual sediment yield using a distributed approach. Earth Surface Processes and Landforms 26(11): 1221-1236.

Vanoni VA (1975) Sedimentation Engineering, Manual and Report No. 54. American Society of Civil Engineers, New York, N.Y.

Vigiak O, Okoba BO, Sterk G, Groenenberg S (2005) Modelling catchment-scale erosion patterns in the East African Highlands. Earth Surface Processes and Landforms 30(2): 183-196.

Xu Z, Lin Z, Zhang M (2007) Loess in china and loess landslides. Yanshilixue Yu Gongcheng Xuebao / Chinese Journal of Rock Mechanics and Engineering 26(7): 1297-1312.

Yang M, Li X-Z, Hu Y-M, He X-Y (2007) Annual sediment yield in sub-watersheds at upper reaches of Minjiang River: A simulation with SEDD model. Chinese Journal of Applied Ecology 18(8): 1758-1764. 
Fig 1 Geographic situation of the study area in the province of Huesca (Spain). Monthly precipitation at the weather station of Canelles and map of land-uses and geomorphic features of the Estaña catchment.

a)
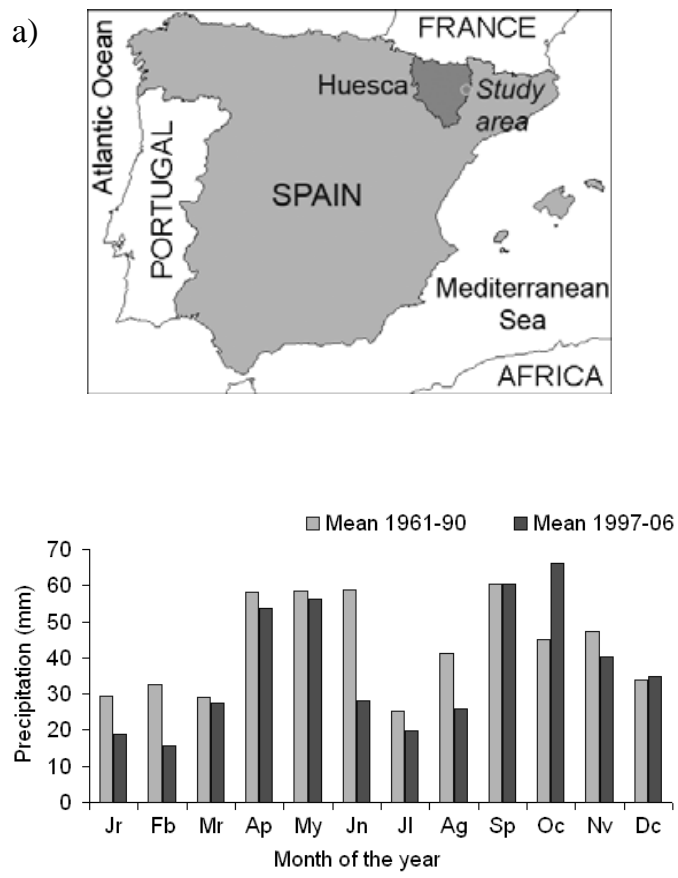

Map of land use एवake Land use

$\square$ Urban Path $\square$ Barley Pasture

Old ab. field Recent ab. field Bare soil Boulder ground Oak

Dense Med. forest Open Med. forest Dense scrubland Sparse scrubland Poplar

Bank vegetation

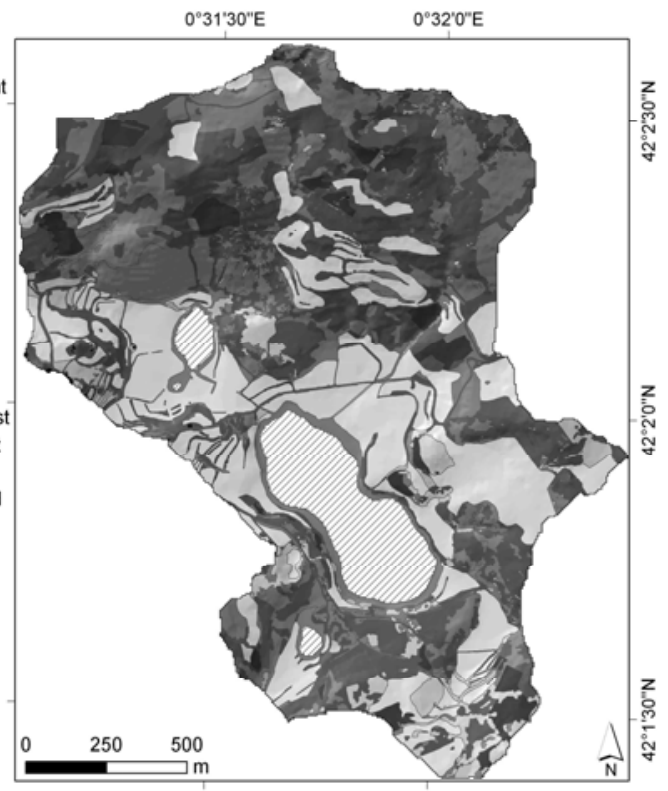

b) Geomorphic map

Geology

AA Keüper Facies (gypsum)

푤표 Keüper Facies

Muschelkalk Facies

Structural elements

ـScarp on limestones

- Contour line

Surface of erosion

Miocene surface

Karstic elements

Lapies

$\square$ Uvala

$\square$ Doline

Collapse doline

$\therefore$ Doline deposit

" [ . , Northern limit of paleopolje

Hydrological elements

- Spring

- Ephemeral stream

$\square$ Gully

A :- Alluvial deposit

Valley floor deposit

Endorheic elements

Lake

Limit of endorheic catchment

-...-. Interfluve

Gravitational elements

Boulder ground

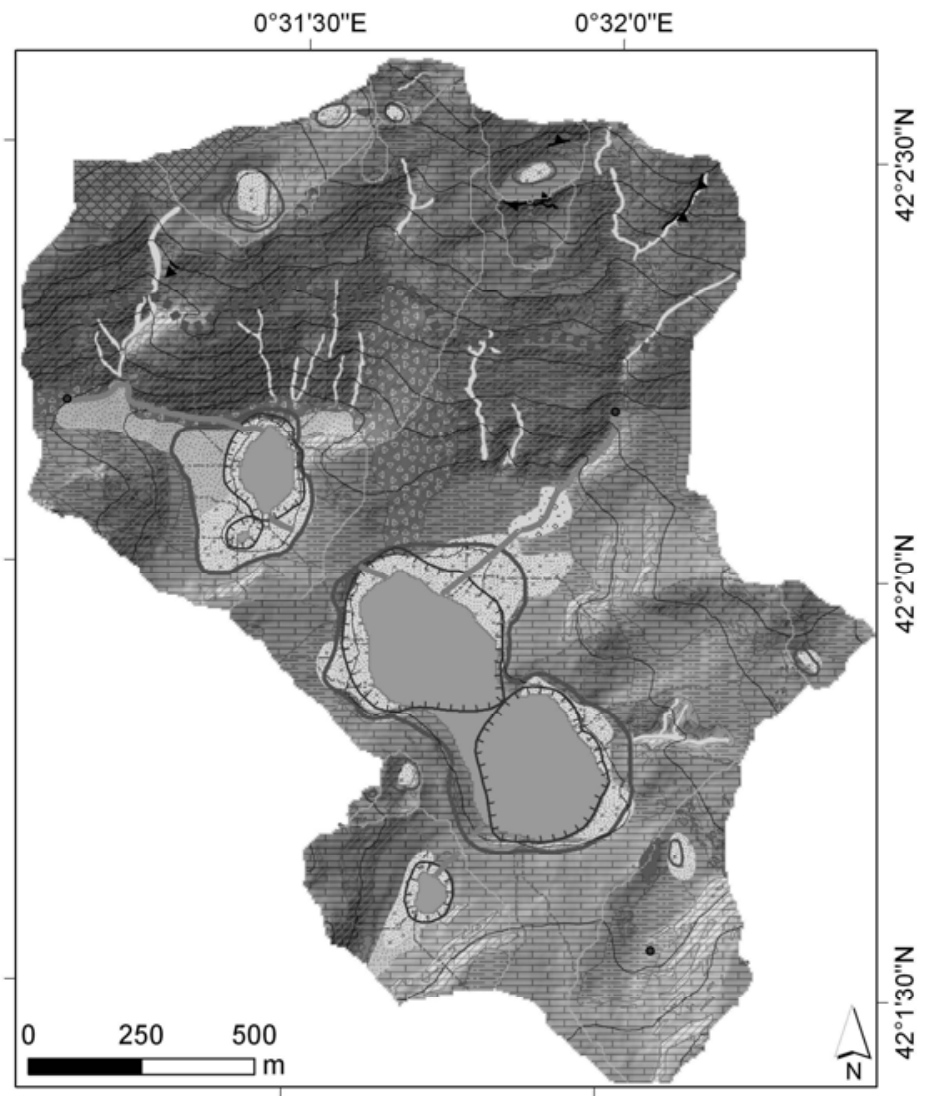

Steep slope

Be물렬 Colluvial deposit

Anthropogenic elements

- Water canal 
Fig. 2 Map of soil detachment by splash and by runoff, histogram of the map of total soil detachment and map of runoff transport capacity (RMMF model) at the Estaña catchment (NE Spain).

a)

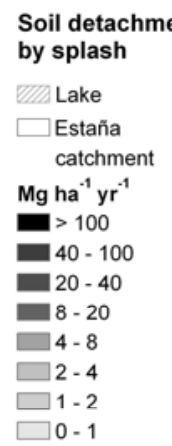

- 1

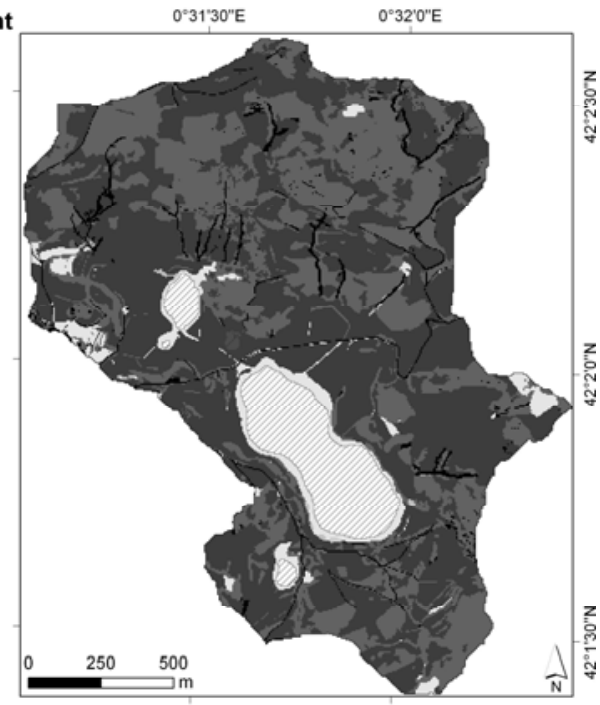

c)

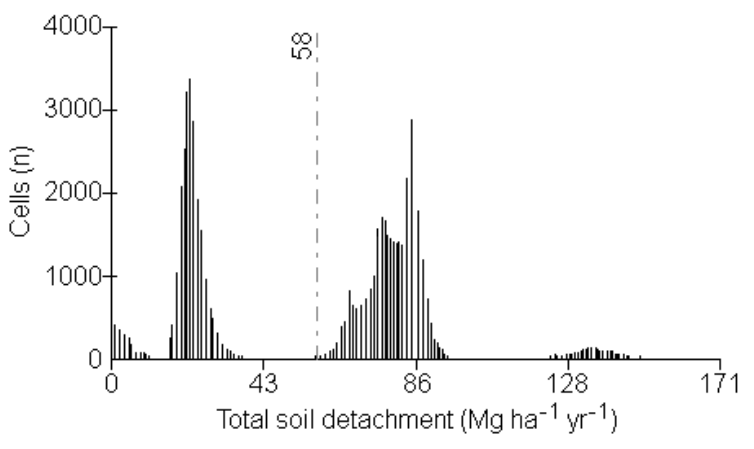

b)

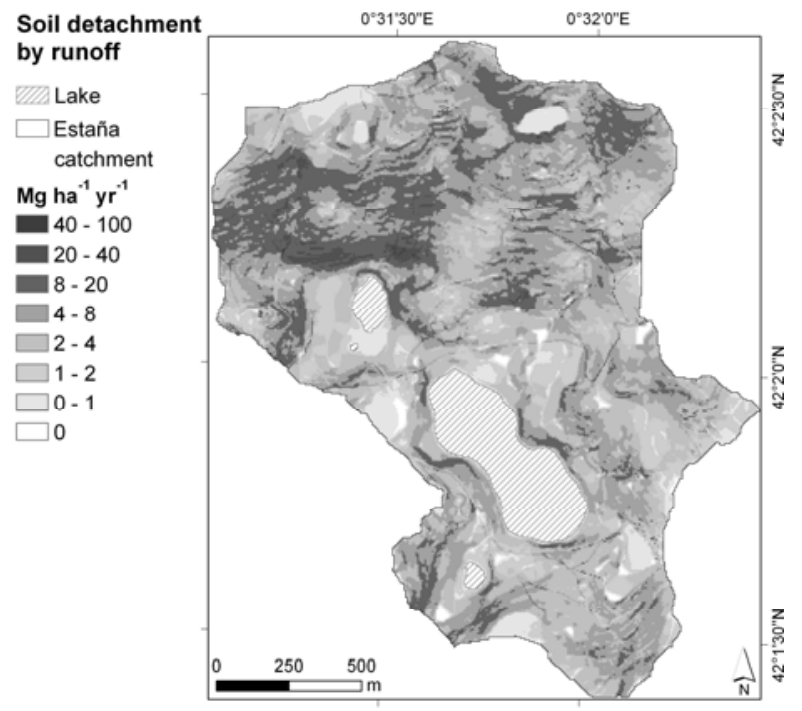

d)

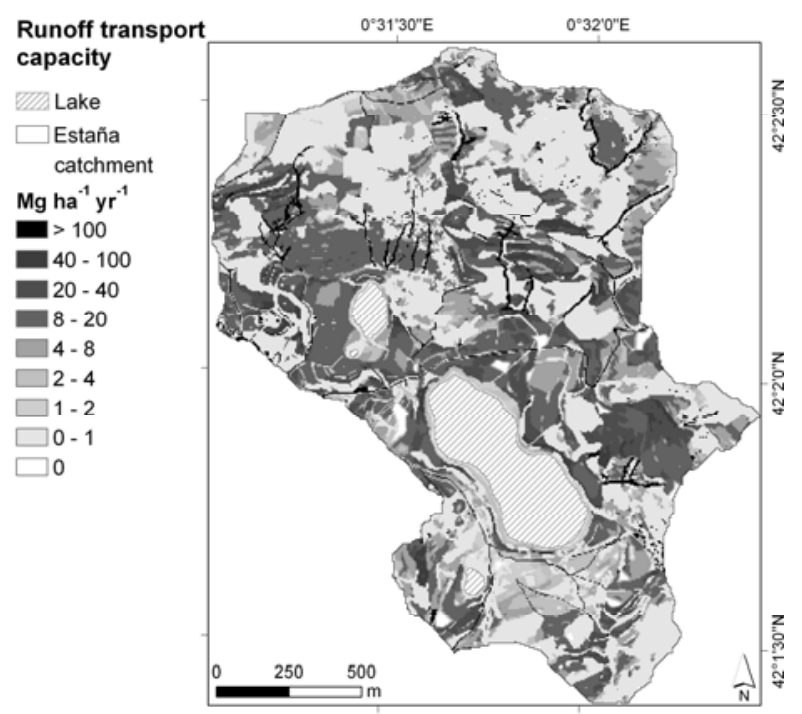


Fig. 3 Map of estimated soil erosion (RMMF model) at the Estaña catchment (NE Spain). Correlation between the average soil erosion $\left(E_{W}\right)$ and the area $\left(A_{W}\right)$ of the different sub-catchments and between $E_{W}$ and the percentage of the surface area of the sub-catchment covered with natural vegetation $\left(A_{W}-N a t\right)$.

a)

\section{Soil erosion}

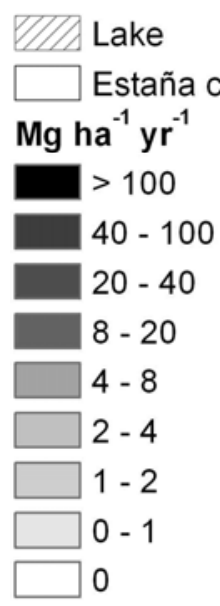

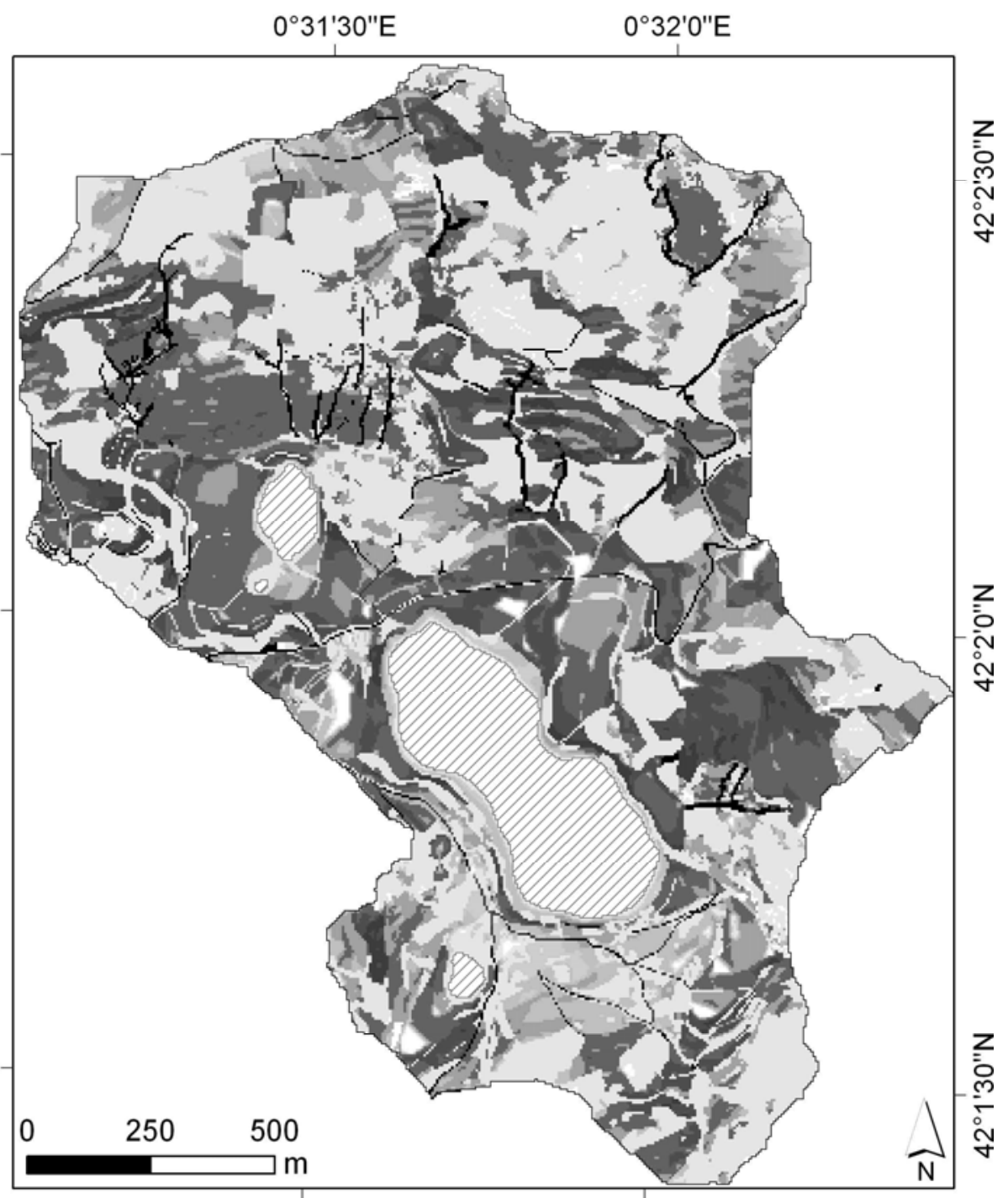

b)

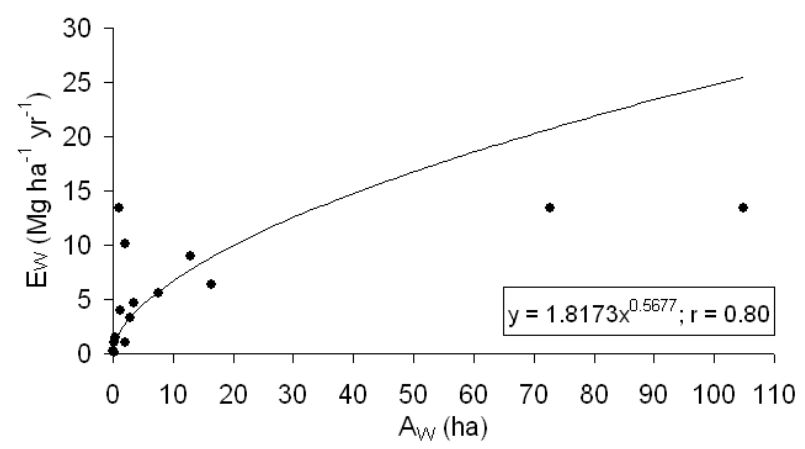

c)

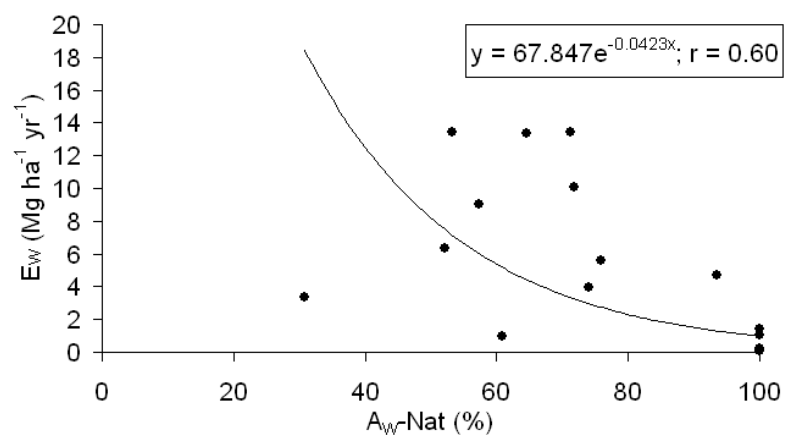


Fig. 4 Simplified map of geomorphic elements at the Estaña catchment (NE Spain) and estimated (RMMF model) and measured ( ${ }^{137} \mathrm{Cs}$; López-Vicente et al., 2008b) values of soil erosion at six control points.

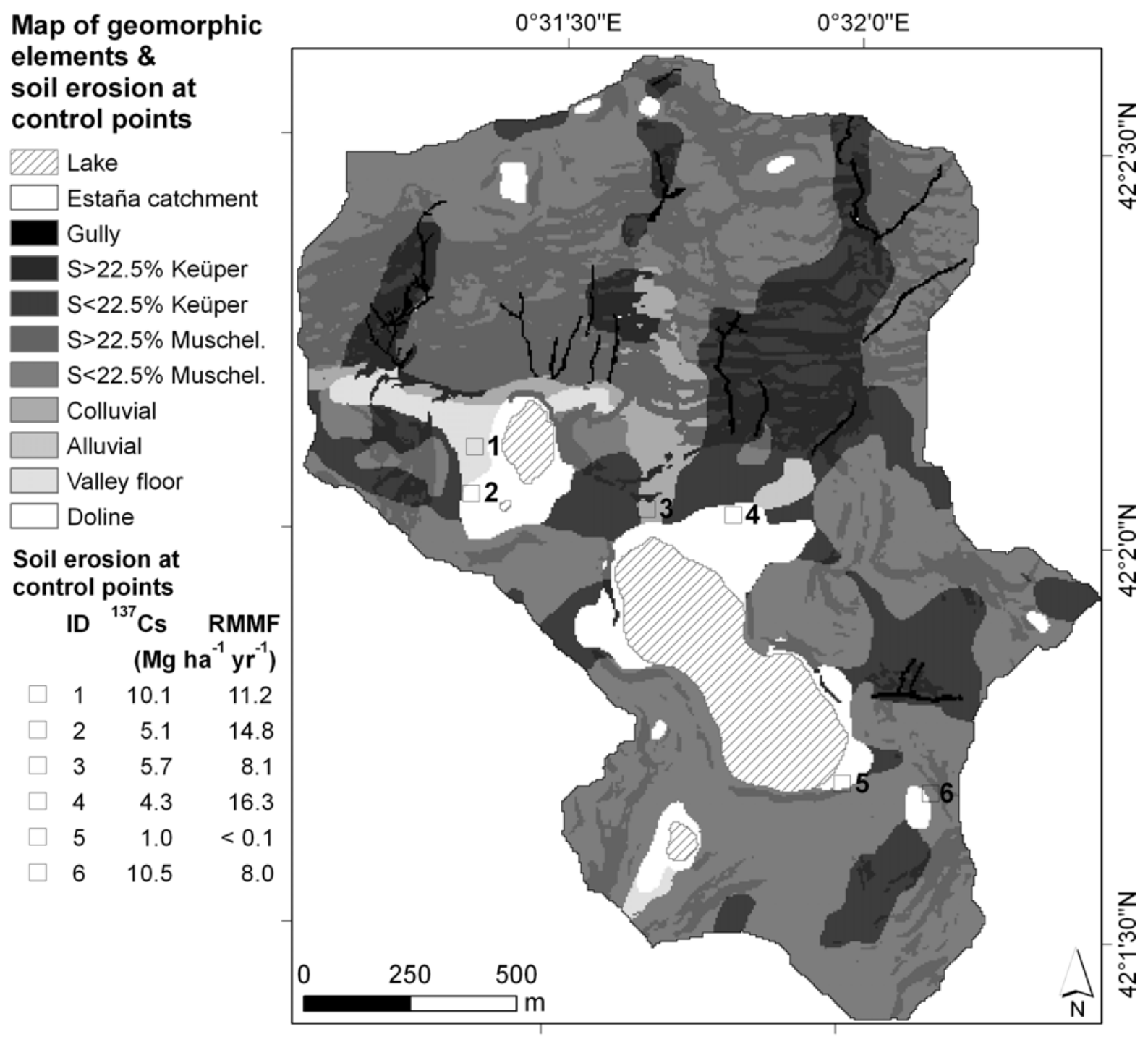


Fig. 5 Histograms of estimated soil erosion (RMMF model) for the different geomorphic elements at the Estaña catchment (NE Spain). T: Tolerable soil loss; $\mathrm{E}_{\mathrm{m}}$ : Mean soil erosion; $\mathrm{E}_{\mathrm{max}}$ : Maximum soil erosion.
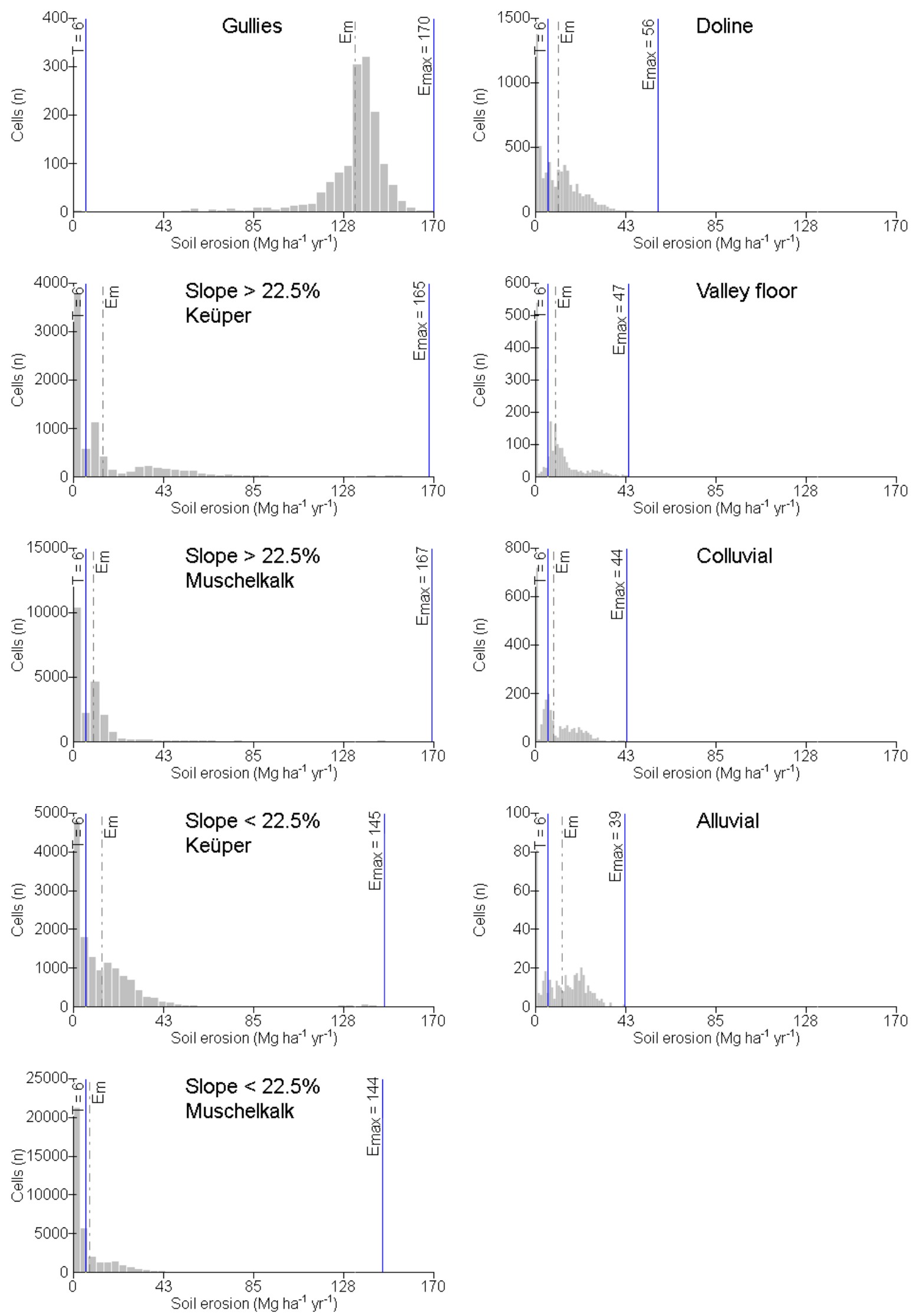
Fig 6 Map of estimated flow velocity $\left(v_{i}\right)$ and sediment delivery ratio $\left(S D R_{i}\right)$ with the SEDD model. Correlation between the sediment delivery ratio $\left(S D R_{W}\right)$ and the catchment area $\left(A_{W}\right)$ and between $S D R_{W}$ and the main stream length $\left(M S L_{W}\right)$ of the different sub-catchments of the study area.

a)

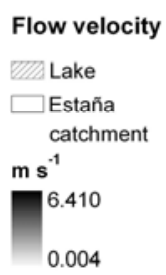

c)
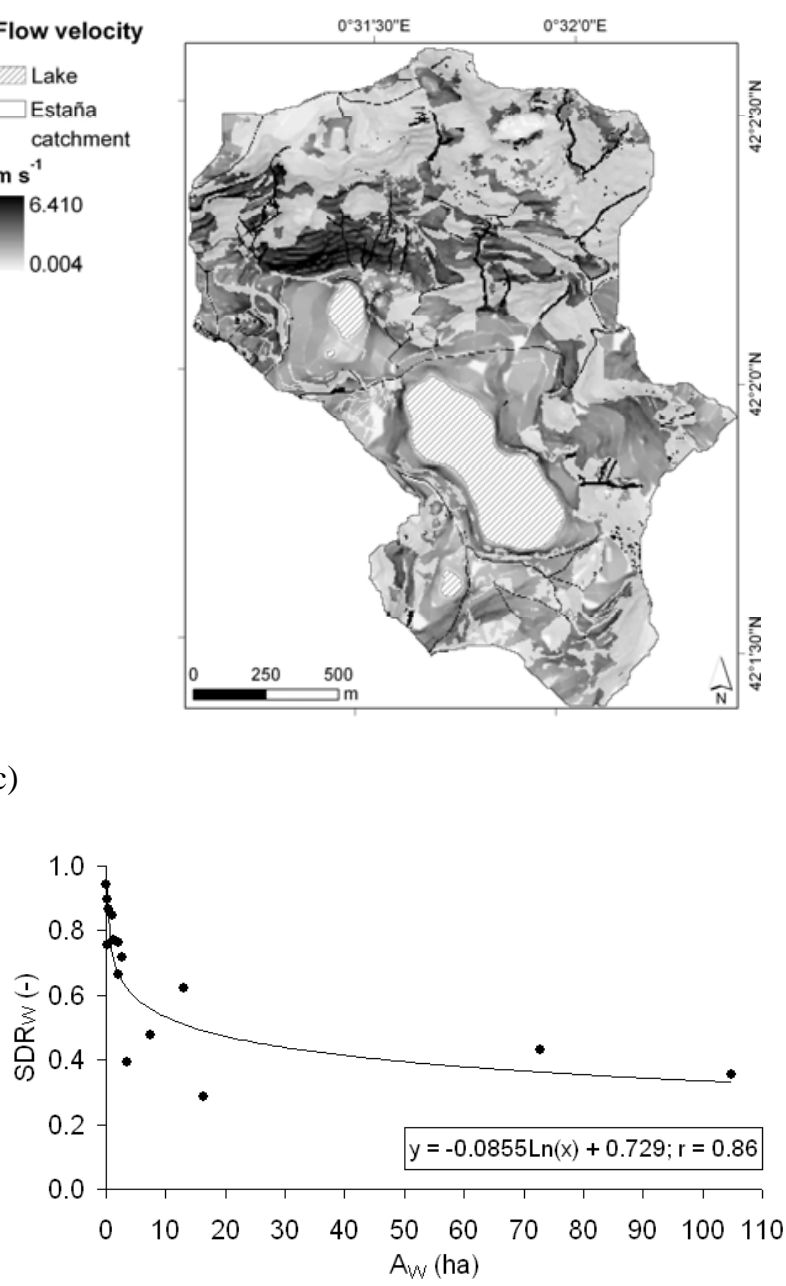

b)

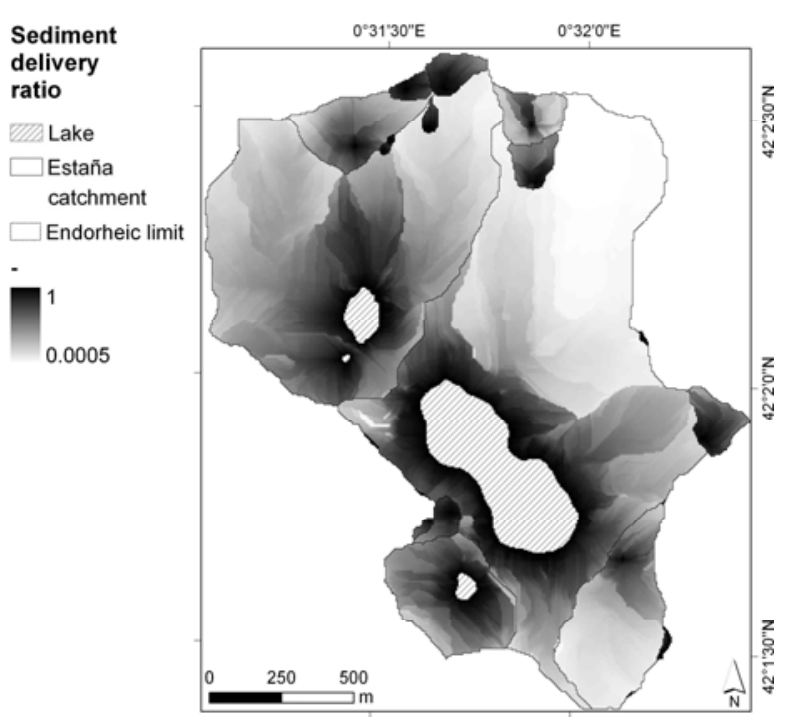

d)

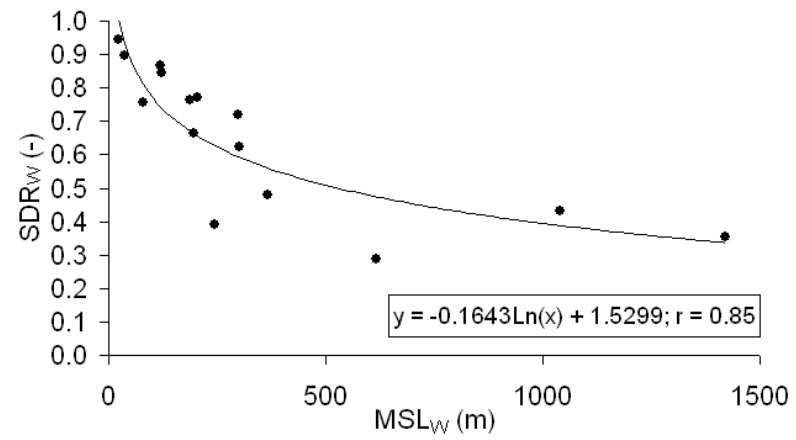


Fig. 7 Map of estimated sediment yield (RMMF and SEDD models) at the Estaña catchment (NE Spain). Correlation between the average sediment yield $\left(S Y_{W}\right)$ and percentage of the surface area with natural vegetation $\left(A_{W}-N a t\right)$. Relationship between percentage of intra-basin stored sediment $\left(I S S_{W}\right)$ and catchment area $\left(A_{W}\right)$ of the different sub-catchments of the study area.

a)

\section{Sediment yield}

\begin{tabular}{|c|c|}
\hline & Lake \\
\hline & Estaña ca \\
\hline & $a^{-1} y^{-1}$ \\
\hline & $>100$ \\
\hline & $40-100$ \\
\hline & $20-40$ \\
\hline & $8-20$ \\
\hline & $4-8$ \\
\hline & $2-4$ \\
\hline & $1-2$ \\
\hline & $0-1$ \\
\hline & 0 \\
\hline
\end{tabular}

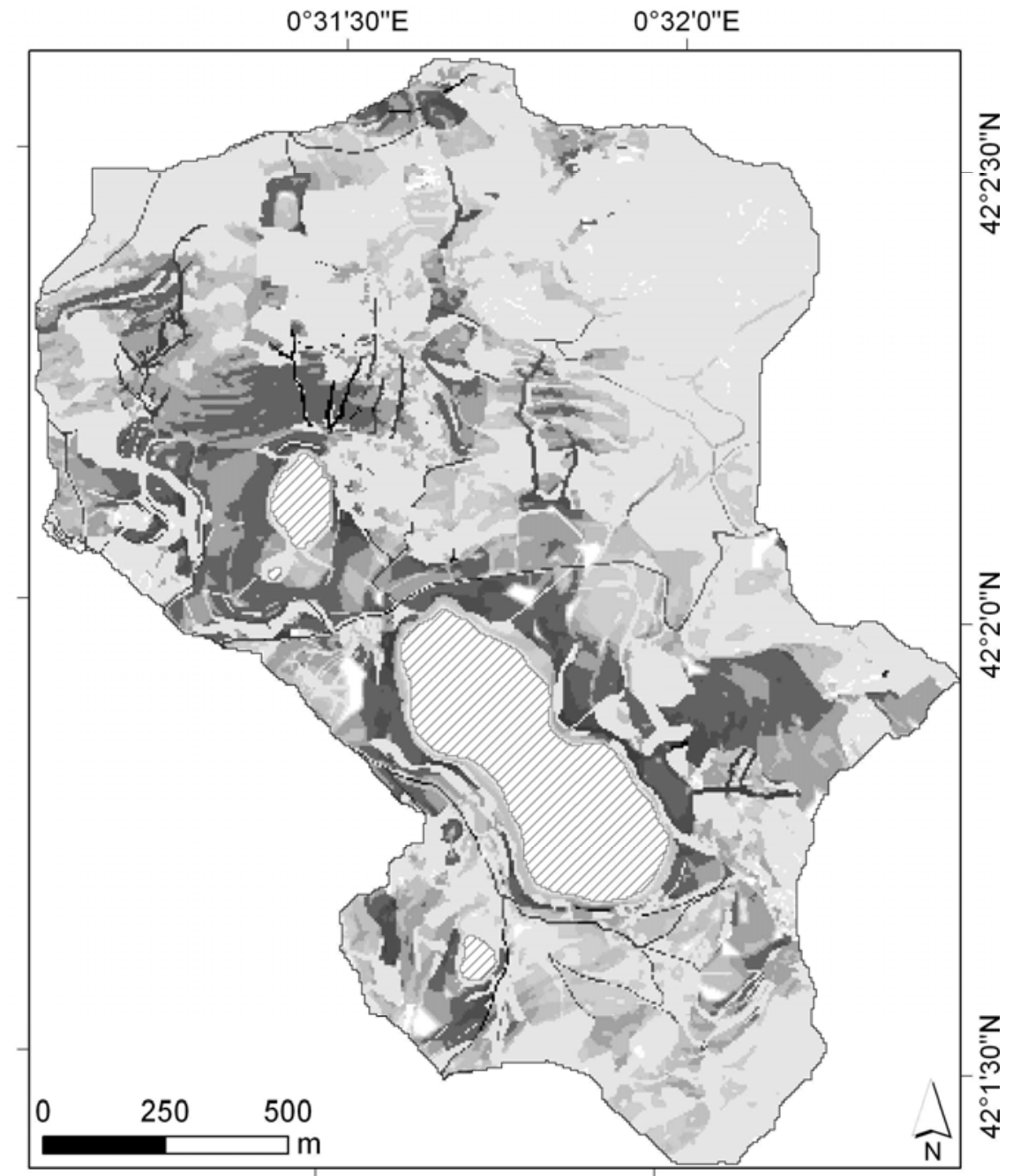

c)
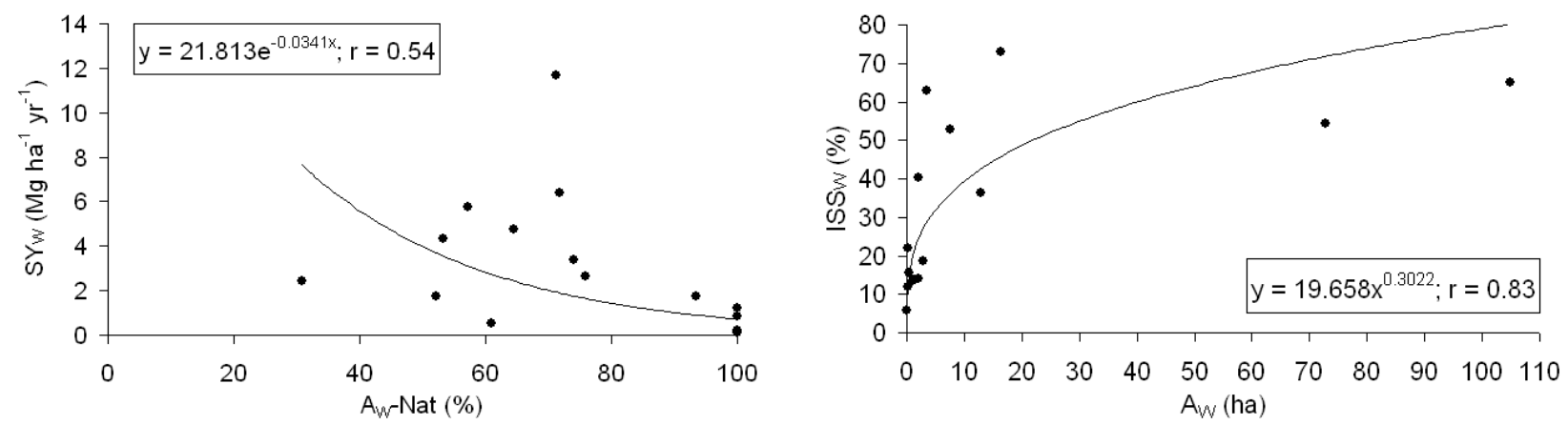
Table 1 Soil detachability $(\mathrm{K})$ and cohesion $(\mathrm{COH})$ of soil types in the Estaña Catchment (NE Spain).

\begin{tabular}{lrr}
\hline Soil texture & $\mathrm{K}\left(\mathrm{g} \mathrm{J}^{-1}\right)$ & $\mathrm{COH}(\mathrm{kPa})$ \\
\hline Sand & 1.2 & 2 \\
Loamy sand & 0.3 & 2 \\
Sandy loam & 0.7 & 2 \\
Loam & 0.8 & 3 \\
Silt & 1.0 & - \\
Silt loam & 0.9 & 3 \\
Sandy clay loam & 0.1 & 3 \\
Clay loam & 0.7 & 10 \\
Silty clay loam & 0.8 & 9 \\
Sandy clay & 0.3 & - \\
Silty clay & 0.5 & 10 \\
Clay & 0.05 & 12 \\
\hline
\end{tabular}

Table 2 Surface area $(A)$ and average soil loss $\left(E_{i}\right)$ of the land uses in the Estaña Catchment (NE Spain).

\begin{tabular}{|c|c|c|c|c|c|}
\hline \multirow[t]{2}{*}{ Land use type } & & \multicolumn{2}{|c|}{$\mathrm{A}$} & \multicolumn{2}{|l|}{$\mathrm{E}_{\mathrm{i}}$} \\
\hline & & ha & $\%^{1}$ & $\mathrm{Mg} \mathrm{ha}^{-1} \mathrm{yr}^{-1}$ & $\%^{2}$ \\
\hline \multirow{6}{*}{$\begin{array}{l}\text { Anthropogenic } \\
\text { use }\end{array}$} & Paths and urban areas & 3.4 & 1.3 & $106.3^{*}$ & $13.3^{*}$ \\
\hline & Winter barley & 65.0 & 28.5 & 20.6 & 49.4 \\
\hline & Pasture & 4.9 & 2.2 & 0.2 & $<0.1$ \\
\hline & Orchard & 1.1 & 0.5 & 5.5 & 0.2 \\
\hline & Old abandoned field & 10.5 & 4.6 & 0.3 & 0.1 \\
\hline & Recent abandoned field & 9.2 & 4.0 & 6.0 & 2.0 \\
\hline \multirow{10}{*}{$\begin{array}{l}\text { Natural } \\
\text { vegetation }\end{array}$} & Boulder ground & 1.1 & 0.5 & - & - \\
\hline & Bare soil & 3.8 & 1.7 & 133.0 & 18.6 \\
\hline & Oak forest & 8.4 & 3.7 & 0.2 & 0.1 \\
\hline & Dense Mediterranean forest & 40.7 & 17.8 & 0.2 & 0.3 \\
\hline & Open Mediterranean forest & 40.6 & 17.8 & 7.7 & 11.5 \\
\hline & Dense scrubland & 21.8 & 9.5 & 0.1 & 0.1 \\
\hline & Disperse scrubland & 11.5 & 5.0 & 9.7 & 4.1 \\
\hline & Poplar & 0.4 & 0.2 & 0.1 & $<0.1$ \\
\hline & Bank vegetation & 5.3 & 2.3 & 1.7 & 0.3 \\
\hline & Pine woodland & 0.6 & 0.2 & 0.1 & $<0.1$ \\
\hline
\end{tabular}

\footnotetext{
* Without considering urban areas. ${ }^{1}$ Proportion of the total surface area, and ${ }^{2}$ Total amount of eroded soil within the Estaña Catchment.
} 
1 Table 3 Estimates of surface area $(A)$, average soil loss $\left(E_{i}\right)$, sediment delivery ratio $\left(S D R_{i}\right)$, sediment yield $\left(S Y_{i}\right)$, and intra-element stored sediment $\left(I S S_{i}\right)$ of

2 the geomorphic elements in the Estaña Catchment (NE Spain).

\begin{tabular}{|c|c|c|c|c|c|c|c|c|c|c|}
\hline \multicolumn{3}{|c|}{ Geomorphic element } & \multicolumn{2}{|r|}{$\mathrm{A}$} & \multicolumn{2}{|l|}{$\mathrm{E}_{\mathrm{i}}$} & \multirow[t]{2}{*}{$\mathrm{SDR}_{\mathrm{i}}$} & \multicolumn{2}{|l|}{$\mathrm{SY}_{\mathrm{i}}$} & \multirow{2}{*}{$\begin{array}{c}\text { ISS }_{\mathrm{i}} \\
\%\end{array}$} \\
\hline & & & $\%^{1}$ & \% with crops & $\mathrm{Mg} \mathrm{ha}^{-1} \mathrm{yr}^{-1}$ & $\%^{2}$ & & $\mathrm{Mg} \mathrm{ha}^{-1} \mathrm{yr}^{-1}$ & $\%^{3}$ & \\
\hline \multicolumn{3}{|l|}{ Gullies } & 1.5 & 0 & 133.1 & 17.2 & 0.31 & 42.2 & 13.4 & 68.3 \\
\hline \multirow[t]{4}{*}{ Slopes } & $\mathrm{S}>22.5 \%$ & Keüper Facies & 8.5 & 20 & 12.8 & 10.0 & 0.24 & 3.5 & 6.1 & 74.9 \\
\hline & & Muschelkalk Facies & 23.8 & 7 & 8.6 & 19.4 & 0.39 & 4.1 & 19.9 & 58.2 \\
\hline & $\mathrm{S}<22.5 \%$ & Keüper Facies & 15.1 & 58 & 11.8 & 17.0 & 0.34 & 4.7 & 14.6 & 64.9 \\
\hline & & Muschelkalk Facies & 39.4 & 24 & 5.8 & 26.0 & 0.41 & 3.6 & 28.9 & 54.7 \\
\hline \multicolumn{3}{|c|}{ Alluvial } & 0.4 & 76 & 11.6 & 0.4 & 0.21 & 2.2 & 0.2 & 80.6 \\
\hline \multicolumn{3}{|c|}{ Colluvial } & 2.6 & 36 & 8.4 & 1.8 & 0.47 & 3.9 & 2.1 & 53.4 \\
\hline \multicolumn{3}{|l|}{ Doline } & 6.7 & 73 & 10.4 & 5.9 & 0.82 & 8.3 & 11.5 & 19.9 \\
\hline \multicolumn{3}{|c|}{ Valley floor } & 2.0 & 70 & 10.1 & 1.7 & 0.64 & 6.4 & 2.6 & 37.0 \\
\hline
\end{tabular}

$3 \frac{}{1}$ Proportion of the total surface area, ${ }^{2}$ Total amount of eroded soil, and ${ }^{3}$ Total sediment yield within the Estaña Catchment . 